\title{
Getting Back on Education: What's Learning Look Like in Indonesian Prison High School?
}

\author{
I Rosmilawati ${ }^{1}$, D Darmawan ${ }^{2}$ \\ \{1irosmilawati@untirta.ac.id, ${ }^{2}$ dadan.darmawan@untirta.ac.id $\}$ \\ ${ }^{1,2}$ Universitas Sultan Ageng Tirtayasa, Serang, Indonesia
}

\begin{abstract}
In Indonesia, 40 million children still live in household that earn less than $\$ 2$ per day, which put them in the poverty line [1]. Many of these young people are imprisoned due to criminal activity such as truancy, small theft in the bus or train station, begging or drug missus, and vagrancy. In Indonesia, there are 3.2 per cent of young people under 18 years of the total prison population. The aims of this study is to examine how young inmates access to Indonesia prison high school and what is learning look like in prison high school? Using qualitative interviews with 40 upper secondary prison-based school students, this study investigated inmate students' pathways on upper secondary education, motivations behind participation and the feeling self-worth in this program. Results indicate that participating in a prison school should be maintained. Most of inmate students in Sekolah Istimewa the Juvenile Special Development Agency (LPKA) Tangerang and Sekolah Terbuka LPKA Bandung entered prison-based high school by; (i) compulsory entrance (ii) voluntary decision; (iii) inclusive educational program; (iv) the role of teacher and prison officer; (v) leisure activities. Despite various reasons, providing education to incarcerated young people can be understood as human right and those who participating in educational activities in the prison may reduce recidivism and increase the likelihood of finding work.
\end{abstract}

Keywords: Prison School, Restorative Justice, Children's Right, Inmate Student.

\section{INTRODUCTION}

Indonesia is one of countries that respects the human right. Right to get education become on the $10^{\text {th }}$ part of the law that can be seen on paragraph 60 of article 1: "every child deserves to get education and learning in developing their personality based on their interest, talent and intelligence." It is include those who deal the law. Based on the data of the Directorate General of Corrections (Directorat Jenderal Permasyarakatan), there are 2.699 in 2019 [2]. Furthermore, the Directorate General of Social Rehabilitation explained that more than 4000 adolescents aged 16-18 years deal with cases of violations of law every year. Many of them are arrested and were brought to court and after going through trial $83 \%$ of children were imprisoned. The Indonesian young people who committed delinquency as explained, is indeed at a fairly high number. Most of these young people deal with minor offences such as theft, truancy, robbery, and vagrancy, or other more serious offences such as drug missus, violence and murder. These young people need social care and education in the prison, otherwise it may cause more offending behaviour and lead to a lifetime of declining health. 
In Indonesia, there are $3.2 \%$ young people under 18 years of the total prison education. There are spread either in Child prison (Lembaga Pembinaan Khusus Anak/LPKA), or adult prison, known as Jail (Rumah Tahanan/RUTAN) and Correctional Institution (Lembaga Permasyarakatan/LAPAS). The Directorat General of Correction (Dirjen Permasyarakatan) under the Ministry of Justice and Human Right (Kementerian Hukum dan Hak Azasi Manusia) manage the Indonesia's prison system. In the sentence, many of these adolescent lost their right on freedom, growing and getting education (Linda, 2010). Only 929 adolescent or 39\% joined formal education, and 175 people or $7 \%$ joined skill training. Prison education for young inmates is very significant dimension of life in prison. For those who dropout from high school because of entering prison, the Indonesian government provide formal (primary, lower secondary and upper secondary school) and nonformal (equivalency education program that include Package A, B and C) education both in LPKA or in RUTAN and LAPAS. Prison education is important to provide meaningful activities for young inmates during imprisonment and it support inmate for life after prison. Education and training in prison, in any level, give young inmate hope and promise. It helps them to find a meaning of life, to show their existence, to determine their conduct and behaviours.

In Indonesia context, prison education refers to educational activities both in long and short term implemented inside prison. These educational activities may include literacy programs, training, vocational skill program, and formal and nonformal secondary school. It might also covers vocational education and tertiary education. Education program in the prison system most funded by the government with support by private sector in voluntary basis. The aims of high school based-prison in Indonesia is not only for decreasing offendingrelated behaviour, but also for acquisition knowledge and skills for future life. The outcome of this type of education is gaining high school certificate so when the young inmate release, perhaps they can continue their education outside or getting a job. Research in prison education has documented various result and benefit on participation in educational prison activities, included the improvement of basic skill [3], reduction of recidivism [4] and contribution of self-worth [5]. Prison-based education, however, remains under-theorised and under-researched in Indonesia. Thus, we raise some questions; what is the nature of schooling in a youth prison? How young inmates access to Indonesia prison high school.

\section{RESEARCH METHOD}

Inductive approach used in this study with employing perspective transformation as a theoretical framework. The aims is to examine the experience of inmate students in prison school with research question: what is the nature of schooling in a youth prison? How young inmates access to Indonesia prison high school? The study was conducted in two high school prisons in Banten and West Java Province, this include Sekolah Istimewa the Juvenile Special development Agency (LPKA) Klas I Tangerang and Sekolah Terbuka LPKA Klas II Bandung. Both high school prison are in children prison, means there is no adult prisoners. This is compulsory for child prison or 'Special Child Development Institution' to provide education for every inmate children, include primary and secondary education level. The LPKA Klas I Tangerang is the oldest children prison in Indonesia and has facilities for inmates over 200 boys between 16 and 18 years old. The LPKA Klas I Tangerang has a wide, calm, tidy and clean yard that pleases the prison occupants and visitors. The young inmates in LPKA often smiled if they meet the researcher or other visitor while they are busy doing activities in the jail. Their everyday activity mostly doing some cleaning, gardening, or cooking in the common kitchen area, LPKA Tangerang has a complete education facilities; it has elementary, 
junior and senior high school and provide some occasional training. Studying activities in LPKA Tangerang start from 07.30 WIB until 11.30 WIB. Similar to LPKA Klas I Tangerang, LPKA Klas II Bandung also has fair school facilities. The area of prisons in LPKA Klas II Bandung bigger than LPKA Tangerang.

A sample of fifty inmate students was recruited using snowball sampling. Snowball sampling is a method to access research informants based on "referrals made among people who share of know of others who possess some characteristics that are of research interest" [6]. The criteria for inmate students participant in this study is that participants must have studied one year in prison high school. Each inmate students involved in in-depth interviews for one to two-hours conversation and it was audio recorded. Ethical considerations include informed consent and anonymity have been delivered to ensure the participants confidentiality so they can speak freely [7].

\section{RESULTS AND DISCUSSION}

The finding of this study demonstrated various pathways taken by young inmates to reparticipate in education program available in the prison. Key factors related to their participation, especially in child prison, is because schooling is mandatory since these young offender arrived into prison. Furthermore, the study also revealed that young inmates have been successfully maintain their motivation of learning as shown by their voluntary decision to re-enter schooling and put their learning activities as leisure.

\subsection{Compulsory Entrance}

Education for young inmates is part of the rehabilitation activities inside the prison. For young inmates in LPKA, schooling is mandatory since they arrived into prison. In Indonesia, since 2014, all child prisoners in LPKA had access to basic and secondary education and other education activities such as training and vocational skills program. When child prisoner enters the prison for the first time, they will be interrogated about their previous educational journey, and suggested to access the prison school that suit them. However, if their retention period is shorter than 1 year, they will be sent to the training centre rather than to education centre (either in basic or secondary education). There is a difference between education and training. Training is a nonformal education activity with focus on specific vocational skill and on employability. On the other hand, education is more long term educational activity both in formal and nonformal pathways to give the inmate students broad knowledge and relatedskills. It also focus on developing the capacity if inmate students for self-critical reflection. If the inmate students completed a particular training in the prison, they will measured by the ability to show their skill in term of "what you can do". Education, in the other hand, is measured by the ability of inmate students to show what they know and apply its knowledge into different aspect of live. In other words, training in prison context is more employmentfocus and it does not constitute as education in the field of adult education [8].

\subsection{Voluntary Decision}

Inmate students in school-based prison may have developmental and psychological problems [9][10]. They also may question the purpose and benefit of education in prison context. But, some young inmate in this study are seeking the educational opportunities available in a prison. For these inmate students, participating in school is voluntary as they 
realise that their educational journey and aspiration have to be maintained even though they are in prison. Most of the young inmates in this group have been pushed out from their previous school while they commit to criminal. On the other hand, for young inmate who has been failing from mainstream school before in prison, their participation is part of obligation or regulation. Most of these young inmates have low skill levels which create the challenges in the schooling process. Teacher and roommates influence a young inmate to participate in education in prison. Teacher who has good relationship with young inmate inspire them to commit with education while in prison.

When young inmates enrol in classes, its means they are participating in the educational activity that force them to act as scholars instead of prisoners. Reading some papers and textbooks are part of daily activities and habits in prison in which prevent them in violence, but to challenge to become scholars. One of the young inmates, Firman, stated that his biggest motivation to attend the prison school was to prove his parent that even though he was a prisoner, he will be able to expand his skills and knowledge for his own good. So, when he release, he will not return to the same "hole" (Firman, 18 years old). Many young inmate feel fortunate with learning opportunity in the prison school until they get a diploma. Based on the most inmate students joined in the interviews argue that in the current era, almost jobs require a diploma and learning opportunity in the prison school is very beneficial for them later after leaving the prison. Lucy, one of the female inmate students stated: "the reason for going to school so I can work and get some money after jail."

\subsection{Inclusive Education Program}

Students commented that school work in the school-based prison was easier than their previous school. Diverse student population with different abilities and backgrounds influence the prison school's manager to develop the educational program more accessible and inclusive for everyone. One of students said:

"I always get trouble in the previous school. Before I came here, I was in year 10 in the public vocational school. But, few weeks before the final examination, the police put me in the jail because of brawl with friends that causes someone's death. Although I have difficult experience in previous school, the prison school accepted me and believe in me as I am (Rama, 17 years old)."

This is line with the study conducted by $\AA$. Diseth et al that most of the prisoners in European countries have weak educational background. Thus, most of the prisoners "need and desire for more formal education program" [11]. The students in this study also commented that a common curricular feature of the prison school was the opportunity to earn easy credits. Almost all the students noted the possibility easy credits at some point in their interviews, most often in response to questions about things they like about the prison school. Students also reported appreciating the opportunity to catch up the school lesson they missed, and enabling them to proceed their learning toward high school graduation.

While there were many limitations that the youth prison schools faced, which is some of the inmate students commented about lack of dedicated teachers, but they get the benefit of this unique setting. Many students in other prisons in the European got benefit from the opportunities to use their schools and to express what they had learned in the prison classroom [12]. Many inmate students enjoy their participation in the prison learning even though they commented on the limited facilities used in the prison. For example, the use of multimedia and internet was very limited due to prison's rule and restriction. While most of students experiencing the marginalization on the learning process, they still appreciate great 
attention from the teachers. Prison education clearly play a positive role on students to achieve academic goals. The constructive relationship between inmate students and with teachers often attribute to positive learning experiences.

\subsection{The Role of Teacher and Prison Officer}

In the Republic of Indonesian Government Regulation Number 32 of 1999 concerning the Term and Procedures for the Implementation of the Rights of Citizens, it states that education and teaching are conscious efforts to prepare prisoners through guidance or training activities for their future roles. In both LPKA Tangerang and Bandung, teachers and prison officers usually offer and even force inmate to enrol in school program. One of the young inmate stated:

"before I did not know that in the prison there was a school for prisoners. I was offered by tutors who taught at the school and the tutors gave advice to follow the learning at the school (Firmansyah, 17 years old)."

Although it seems that some prison officers forced the young inmate to go to prison school, but for a young prisoner like Aldi, he feel unmotivated when he said: "Actually, I don't want to study at school anymore. I am so lazy to come to the classroom." Of course, the reason for not wanting to go to school was revealed by Aldi because he did not yet have an awareness of education that was important for his future. During the initial process of going to school, they are provided with school supplies. Such a learning coercion happened in prison school, it is indeed adjusted to the characteristics of the prison, because every prison and its inmates has varied learning characteristics. Indeed, some young inmates are difficult to manage and it force the teachers act as provocateur and police officer [13].

\subsection{Leisure Activities}

The schooling process in correctional institution make prisoners feel like having leisure activities in prison other than just westing time in the jail. This is also may reduce the level of stress that can be arise anytime. The daily practice of the inmates start from 4.30 that they have to wake up and do the morning prayer, clean up the blocks and prepare for the morning ceremony at $8.00 \mathrm{am}$. Every morning, all young inmates must attend the morning ceremony in which they will be check by the officer. After breakfast, the young inmates ready for school until noon time. For some inmates who not join the schooling activities, they spend time in the blocks almost whole day.

Activities in prison school also include art and sports activities. Many arts and sports activities are carried out in prisons such as futsal and angklung. The exercise programs in educational activities in prison school will increase the health and wellness of the young inmates [14]. Furthermore, Bersimon et al. [15] also stated that art program such as music "decreases anxiety and anger level of the young inmates." Even this activities in not mandatory, many inmate students joined the activities because it such like a leisure activities for them. This aims to provide the young inmate with a healthy soul and good mind. One of the students said: "it brings happiness for me and I like playing basketball" (Febri, 17 years old). Every inmates students have a different spirit. There are some who have high enthusiasm, but some are lazy to attend school. For the inmate students in this group, it is clear that prison school activities is like leisure activities in which it gives them privilege to encounter other experience in the prison other than spend time behind bars [16]. 


\section{CONCLUSIONS}

Getting education, health and proper life is a right for all Indonesia, especially for children. Education can be gateway to social and economic mobility for young inmate after release from prison. Investing education in prison provides the opportunity for young inmate to thrive in the future regardless of their past. It also give the greatest benefit to society as a whole in which the young inmate will leave together with society after release. Providing education for young offenders also should be understood as a the obligation of the government to meet educational need of every children as part of the the human right. It means that the prison education should not only be understood as a conception of efficacy. Educational activities in the prison may help young prisoners relieve the boredom of prison and build a positive socialisation with prison community. In the long future, it also open up the opportunity to increase employability in the future.

\section{ACKNOWLEDGMENT}

This research study is funded by the Directorate for Research and Community Services, Directorate General of Research and Development, Ministry of Research, Technology and Higher Education of the Republic of Indonesia.

\section{REFERENCES}

[1] Unicef, "Equity in public financing of water, sanitation and hygiene (WASH) Indonesia," no. June, p. 52, 2016.

[2] D. G. of Corrections, "The Latest Data of The Number of Residents of The Regional Office," Jakarta, 2015.

[3] J. S. Vacca, "Are Less Likely to Return to Prison,” J. Correct. Educ. Correct. Educ. Assoc. J. Correct. Educ. J. Correct. Educ., vol. 55, no. 554, pp. 297-305, 2004.

[4] J. Petersilia, When prisoners come home: Parole and prisoner reentry. Oxford: University Press, 2003.

[5] A. Coyle, A human rights approach to prison management, vol. 13, no. 2. 2003.

[6] P. Biernacki and D. Waldorf, "Snowball Sampling: Problems and Techniques of Chain Referral Sampling," Sociol. Methods Res., vol. 10, no. 2, pp. 141-163, 1981.

[7] L. Cohen, L. Manion, and K. Morrison, Research Method in Education. London: Routledge, 2009.

[8] A. Costelloe and K. Warner, "Prison education across Europe: Policy, practice, politics," London Rev. Educ., vol. 12, no. 2, pp. 175-183, 2014.

[9] L. Kellam, "Target programs: An analysis of the impact of prison program participation on community success," Albany, NY, 2007.

[10] S. J. ; Steurer, L. Smith, A. Tracy, and S. J. Steurer, "Submitted to the Office of Correctional Education United State Department of Education," Reports Res., no. 143, 2001.

[11] A. Diseth et al., Prisoners' Educational Background, Preferences and Motivation. 2009.

[12] J. S. Matthew and E. S.-D. Timothy, "Structure of Intellect and Learning Style of Incarcerated Youth Assessment: A Means to Providing a Continuum of Educational Service in Juvenile Justice," J. Correct. Educ., vol. 56, no. 4, p. 347, 2005.

[13] I. Rosmilawati and S. Suherman, "Secret Teacher," 2019, vol. 253, no. Aes 2018, pp. 
271-274.

[14] D. Gallant, E. Sherry, and M. Nicholson, "Recreation or rehabilitation? Managing sport for development programs with prison populations," Sport Manag. Rev., vol. 18, no. 1, pp. 45-56, 2015.

[15] M. Bensimon, T. Einat, and A. Gilboa, "The impact of relaxing music on prisoners' levels of anxiety and anger," Int. J. Offender Ther. Comp. Criminol., vol. 59, no. 4, pp. 406-423, 2015.

[16] N.K. Juliantari, I.K. Sudarsana, N.K. Sutriyanti, I.N.T. Astawa, I.D.A.H. Putri, and K. Saddhono. "Educational Games Based in Information Technology as Innovation Evaluation Activity in Learning." In IOP Journal of Physics: Conference Series, vol. 1114 no. 1, p. 012041 . IOP Publishing, 2018. 